\title{
STUDIES ON A CONTAGIOUS ECTHYMA-LIKE DISEASE OBSERVED AMONG THE SHEEP
}

\author{
YUTAKA ASAKAWA, KIYoshi IMAIZUMI AND Yoshio TAJIMA \\ The National Institute of Health \\ MOTOSHIGE ENDO \\ The Institute for Infectious Diseases, Tokyo University
}

(Received July 7th, 1952)

\section{Introduction}

In autumn 1948, an eruptive dermatitis accompanied with fever occurred, propagating one after another, among the sheep bred in the Veterinary Division of the National Institute of Health. Later in June 1950, outbreaks of the same disease were observed in Yamanashi Prefecture and also in some other provinces. Following are the brief summaries of the etiological investigations carried out.

\section{Occurrence and symptoms of the disease}

On october 6th 1948, dark-brownish scab was found formed on the periphery of the lips of a sheep which was in our laboratory for the purpose of obtaining blood. Observation was continued and a few days later, 8 sheep out of the total 11 were found infected developing symptomes. Details are as shown in Table I. The main symptom was of eruptive dermatitis. First, there were formed erythematous papules or vesicles, the sizes of which were varying from miliary to red bean with irregular periphery. They became purulent, and then, dark-brownish scabs were formed and exuviated. The lesions were found mostly on the face, especially on the lips, and sometimes on the inner femoral portion and scrotum, but never found on the part of the skin covered with long hair. Occasionally, exanthema formed on the lip fused into one large lesion and was found covered with dark- brownish scab (Fig. 1). The majority of infected sheep developed fever (over $40^{\circ} \mathrm{C}$ ) but other systemic changes were not observed except slight anorexia and dejection. Generally, 2-3 weeks after, the scab exuviated and healed. Prognosis was favorable and not a single sheep proved fatal. 
Table I

Occurrence of a contageous ecthema-like disease among the sheep bred in the Veterinary Division, N.I.H.

(October, 1948)

\begin{tabular}{|c|c|c|c|c|c|c|c|c|}
\hline \multirow{2}{*}{ No. } & \multirow{2}{*}{ Sex } & \multirow{2}{*}{$\begin{array}{l}\text { Date } \\
\text { found }\end{array}$} & \multicolumn{4}{|c|}{ Exanthema } & \multicolumn{2}{|c|}{ Body temperature } \\
\hline & & & Face & Lip & $\begin{array}{l}\text { Scro- } \\
\text { tum }\end{array}$ & Thigh & Febrile stage & Maximum \\
\hline 1 & $\delta$ & $6 / X$ & +++ & ++ & ++ & + & $1 / \mathrm{X}, 14 / \mathrm{X}, 15 / \mathrm{X}$ & $40.9^{\circ} \mathrm{C}$ \\
\hline 2 & 우 & $9 / \mathrm{X}$ & + & + & - & - & $9 / X-11 / X$ & $40.1^{\circ} \mathrm{C}$ \\
\hline 3 & $\delta$ & $=$ & - & ++ & - & - & $9 / \mathrm{X}-15 / \mathrm{X}$ & $40.2^{\circ} \mathrm{C}$ \\
\hline 4 & $"$ & $11 / \mathrm{X}$ & + & - & - & - & $10 / \mathrm{X}$ & $40.6^{\circ} \mathrm{C}$ \\
\hline 5 & $=$ & $12 / \mathrm{X}$ & + & - & 2 & - & $9 / \mathrm{X}-10 / \mathrm{X}$ & $40.6^{\circ} \mathrm{C}$ \\
\hline 6 & 우 & $6 / \mathrm{X}$ & + & + & - & - & $9 / \mathrm{X}$ & $39.8^{\circ} \mathrm{C}$ \\
\hline 7 & $\delta$ & $12 / \mathrm{X}$ & + & + & $2-3$ & 1 & $9 / \mathrm{X}-16 / \mathrm{X}$ & $40.7^{\circ} \mathrm{C}$ \\
\hline 8 & $"$ & $=$ & 1 & - & - & - & $9 / \mathrm{X}$ & $40.1^{\circ} \mathrm{C}$ \\
\hline 9 & $=$ & - & - & - & - & - & - & - \\
\hline 10 & $"$ & $\bullet$ & - & - & - & - & • & • \\
\hline 11 & $"$ & - & - & - & - & - & - & - \\
\hline
\end{tabular}

Notes: Plus sign designates the number of exanthema. +++ for more than $21,++$ for $11-20,+$ for $5-10$.

Occurrence of a contageous ecthema-like disease was first noted some ten days after the arrival of a sheep from Fukushima Prefecture which was placed in the same hutch with old ones. The sheep came from Fukushima Prefecture is thus considered as the source of the infection, and investigations were made in the sheep-raising districts of the said prefecture, whereupon, a disease quite similar to the present disease was found endemic in those areas. But in Fukushima Prefecture, authors failed to have a chance to study the materials collected from field examples. Later in June 1950, being informed of an occurrence of the same disease in Kitakoma, Yamanashi Prefecture, investigations were undertaken at the place of occurrence. However, the epizootic period had ended before the investigations were started, and detailed observations were not practicable. The findings obtained are summarized as follows:

On June 11th, outbreaks of the disease were reported in Masutomi village on 7 out of 16 and in Sinoo village on 7 out of 21 among one year old sheep bought from Yamagata Prefecture which were distributed to 
several villages. In both villages, the infected sheep developed symptoms about 3-10 days after the arrival of new sheep. Their principal symptoms, progress of the disease and prognosis were quite similar to those of the afore mentioned. In Shinoo village, as the infected sheep was also mixed with goats, propagation of the disease to goats was also observed.

\section{Experimental infection to sheep and goats.}

Since this disease is believed to be contagious judging from the abovementioned findings, various experimental infections to sheep and goats were undertaken.

1. Experiments made with the scab emulsion

1). Ear and dorsal skin of two healthy sheep (No. 12, No. 13) were scarified, and an emulsion of the primary scab of naturally infected sheep (No. 1, 2, 3, 4, and 6) was applied on the site scarified. The animals thus infected became feverish and developed local exanthema which formed scab, proving that the infection had taken place. A sheep reinfected (No. 12) 26 days afterwards showed no particular changes and was believed it had acquired immunity to some extent against the infection.

2). Emulsion of the scab obtained from experimentally infected sheep (No. 12, and 13) and the same mixed with penicillin were inoculated into the dorsal portion of a healthy sheep (No. 17) and a sheep (No. 3) which had experienced natural infection (100 days after contracting the disease). The results are as shown in Table II. At the site of inoculation, Sheep No. 17 developed typical changes with a slight difference according to the locality. At the same time, the animal had fever, diarrhoea, and nasal discharge. On the contrary, neither local nor systemic reactions were observed on Sheep No. 3, likewise to the case Sheep No. 2 used in the preceding experiment, signifying that the animals once experienced this disease acquire immunity to some extent.

3). Emulsion of the scab obtained from an infected sheep in Yamanashi Prefecture was inoculated into the nasal cavity, nose, lips, and thigh of a healthy sheep (No. 21), the results were practically the same as those observed in the experiment mentioned above, giving the positive confirmation of the experimental infection.

2. Experiments made with filtered materials

By the above-mentioned experiments, this disease was proved to be contagious. On the other hand, bacteriological examinations were also per- 


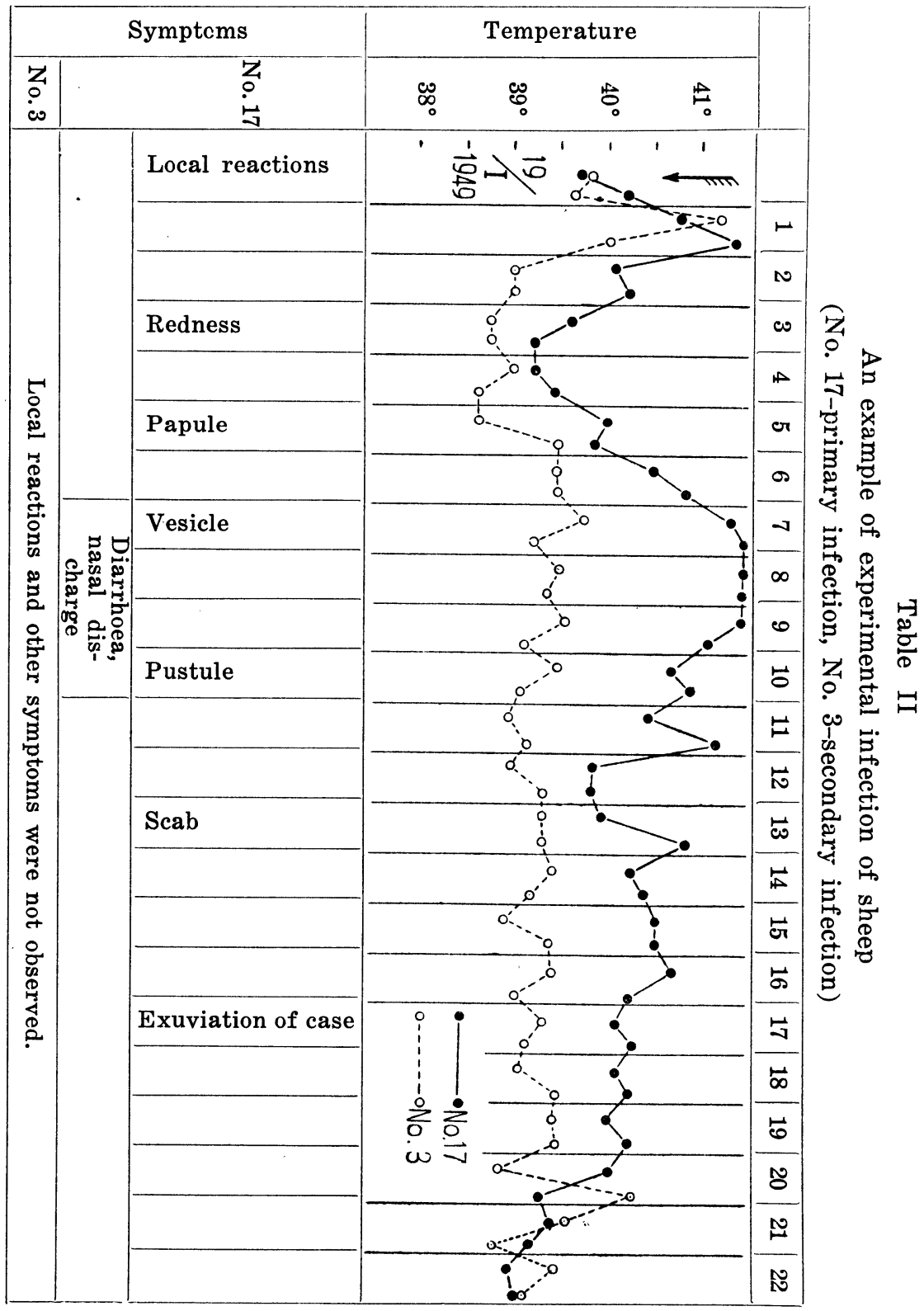


formed from the time when the first observation was made. Staphylococcus and other microorganisms were recovered from the materials collected from the lesion of exanthema and scab, but no organism attributable to the cause of the present infection was found out. Thus, various filltration experiments were made suspecting the presence of virus as a causative agent of the present infection.

1). Martin bouillon emulsion of the scab of a sheep naturally infected (No. 15) and that of a sheep experimentally infected (No. 16) were centrifuged. The supernatant fluids obtained were filtered through Berkefeld $\mathrm{V}$ filter and confirmed of their sterility. The filtrates thus obtained were inoculated into the lip, dorsal portion, and thigh of a healthy sheep (No. 19, 50 days after birth), into two sheep once infected (No. 17, 35 days after infection and No. 5, 125 days after infection) and a healthy goat (No. 1). As controls, the inoculations of with non-filtered materials were also performed. For goat, the serum obtained at the febrile stage (No. 2), nonfiltered materials (No. 3), healthy sheep serum, staphylococcus, and plain bouillon (No. 4) were inoculated separately. The results are as shown in Table III. Sheep No. 19 developed fever, and with non-filtered materials the formation of exanthema and scab was observed on all of the sites inoculated. With filtered materials positive results were obtained only on the lip (Fig 2,3). Regarding the sheep which experienced the infection, Sheep No. 5 developed exanthema on the lip and became slightly feverish, but the formation of exanthema was not observed on Sheep No. 17. The difference in the severity of exanthema formation and in the duration between the first infection and the second infection on Sheep No. 5 and No. 17 appear to indicate to some extent the duration of immunity acquired by those animals which experienced the infection. As for goats, exanthema and scab formations were observed on Goat No. 3 which was inoculated with non-filtered materials (Fig 4), but the result of inoculations made with the filtrates were all negative both on the goats and the sheep in control.

2). The filtrates, prepared in the same manner as in the former experiment, were inoculated on a normal sheep (No. 20) and a goat (No. 5). As shown in Table IV, formations of exanthema and scab were observed on both of them. Exanthema, however, was remarkable on the lip and obscure on the other sites inoculated. When $V$ filtrate was used exanthema appeared earlier with more severity than when $\mathrm{W}$ filtrate was used. Contrary 
Table III

Experimental infection made with filtered material-1.

\begin{tabular}{|c|c|c|c|c|c|c|c|c|}
\hline \multicolumn{4}{|c|}{ Animal } & \multicolumn{2}{|c|}{ Inoculation } & \multicolumn{3}{|c|}{ Reaction } \\
\hline \multirow{2}{*}{ Species } & \multirow{2}{*}{ No. } & \multirow{2}{*}{$\operatorname{Sex}$} & \multirow{2}{*}{ Age } & \multirow{2}{*}{ Material } & \multirow{2}{*}{ Site } & \multirow{2}{*}{$\begin{array}{l}\text { Exan- } \\
\text { thema }\end{array}$} & \multicolumn{2}{|c|}{ Temperature } \\
\hline & & & & & & & $\begin{array}{c}\text { Febrile } \\
\text { stage }\end{array}$ & $\begin{array}{c}\text { Maxim- } \\
\text { um }\end{array}$ \\
\hline \multirow{6}{*}{ Sheep } & \multirow[b]{2}{*}{19} & \multirow[b]{2}{*}{$\delta$} & \multirow{2}{*}{$\begin{array}{c}50 \\
\text { days }\end{array}$} & Filtrate & \multirow{2}{*}{$\begin{array}{c}\text { Dorsal } \\
\text { portion, } \\
\text { thigh, } \\
\text { lip }\end{array}$} & Lip & \multirow{2}{*}{$\begin{array}{c}5-7 \\
\text { days }\end{array}$} & \multirow[b]{2}{*}{$40.4^{\circ} \mathrm{C}$} \\
\hline & & & & Non-filtrated & & $\begin{array}{l}\text { On all } \\
\text { sites in- } \\
\text { oculated }\end{array}$ & & \\
\hline & \multirow{2}{*}{$5^{*}$} & \multirow{2}{*}{$=$} & \multirow{2}{*}{$\begin{array}{c}2 \\
\text { years }\end{array}$} & Filtrate & \multirow{2}{*}{$\begin{array}{c}\text { Dorsal } \\
\text { portion, } \\
\text { lip }\end{array}$} & \multirow{2}{*}{ Lip } & \multirow{2}{*}{$\begin{array}{l}12-16 \\
\text { days }\end{array}$} & \multirow{2}{*}{$40.2^{\circ} \mathrm{C}$} \\
\hline & & & & Non-filtrated & & & & \\
\hline & \multirow{2}{*}{$17 *$} & \multirow{2}{*}{$=$} & \multirow{2}{*}{$\begin{array}{c}1 \\
\text { year }\end{array}$} & Filtrate & \multirow{2}{*}{$=$} & \multirow{2}{*}{-} & \multirow{2}{*}{-} & \multirow{2}{*}{$39.9^{\circ} \mathrm{C}$} \\
\hline & & & & Non-filtrated & & & & \\
\hline \multirow{4}{*}{ Goat } & 1 & q & $\begin{array}{c}4 \\
\text { years }\end{array}$ & Filtrate & $=$ & - & - & $39.8^{\circ} \mathrm{C}$ \\
\hline & 2 & $=$ & $\begin{array}{c}4 \\
\text { years }\end{array}$ & $\begin{array}{c}\text { Serum ob- } \\
\text { tained at } \\
\text { febrile stage }\end{array}$ & $=$ & - & - & $39.5^{\circ} \mathrm{C}$ \\
\hline & 3 & $=$ & $\begin{array}{c}3 \\
\text { years }\end{array}$ & Non-filtrated & $=$ & $\begin{array}{l}\text { On all } \\
\text { sites in- } \\
\text { oculated }\end{array}$ & - & $39.7^{\circ} \mathrm{C}$ \\
\hline & 4 & $\delta$ & $\begin{array}{c}4 \\
\text { years }\end{array}$ & $\begin{array}{c}\text { Normal sheep } \\
\text { serum and } \\
\text { staphyl. }\end{array}$ & $=$ & - & - & $39.5^{\circ} \mathrm{C}$ \\
\hline
\end{tabular}

*Reinfection-Sheep No. 5...125 days after the natural infection (Table I).

Sheep No. $17 \ldots 35$ days after the experimental infection (Table II).

Table IV

Experimental infection made with filtered materials-2

\begin{tabular}{|c|c|c|c|c|c|c|c|c|}
\hline \multicolumn{4}{|c|}{ Animal } & \multicolumn{2}{|c|}{ Inoculation } & \multicolumn{3}{|c|}{ Reaction } \\
\hline \multirow{2}{*}{ Species } & \multirow{2}{*}{ No } & \multirow{2}{*}{ Sex } & \multirow{2}{*}{ Age } & \multirow{2}{*}{ Material } & \multirow{2}{*}{ Site } & \multirow{2}{*}{$\begin{array}{l}\text { Exan- } \\
\text { thema }\end{array}$} & \multicolumn{2}{|c|}{ Temperature } \\
\hline & & & & & & & $\begin{array}{c}\text { Febrile } \\
\text { stage }\end{array}$ & $\begin{array}{c}\text { Maxim- } \\
\text { um } \\
\end{array}$ \\
\hline \multirow{2}{*}{ Sheep } & \multirow{2}{*}{20} & \multirow{2}{*}{ 우 } & \multirow{2}{*}{$\begin{array}{c}6 \\
\text { months }\end{array}$} & V filtrate & \multirow{2}{*}{$\begin{array}{l}\text { Dorsal } \\
\text { portion, } \\
\text { thigh, } \\
\text { lip }\end{array}$} & \multirow{2}{*}{ Lip } & \multirow{2}{*}{7 days } & \multirow{2}{*}{$40.0^{\circ} \mathrm{C}$} \\
\hline & & & & W filtrate & & & & \\
\hline \multirow{2}{*}{ Goat } & \multirow{2}{*}{5} & \multirow{2}{*}{$\delta$} & \multirow{2}{*}{$=$} & V filtrate & \multirow{2}{*}{$=$} & \multirow{2}{*}{$=$} & \multirow{2}{*}{$\begin{array}{l}4 \text { and } \\
12 \text { days }\end{array}$} & \multirow{2}{*}{$40.3^{\circ} \mathrm{C}$} \\
\hline & & & & W filtrate & & & & \\
\hline
\end{tabular}


to the former experiment, positive results were obtained also on goats by the inoculation made with filtered materials. This difference was considered to be due to the difference in sensitivity of the goats used which were of different ages.

3). Experiments were made with the materials obtained from Sheep No. 21 which was infected in Yamanashi Prefecture (Table V). In the

Table V

Experimental infection made with filtered materials-3.

\begin{tabular}{|c|c|c|c|c|c|c|c|c|}
\hline \multicolumn{4}{|c|}{ Animal } & \multicolumn{2}{|c|}{ Inoculation } & \multicolumn{3}{|c|}{ Reaction } \\
\hline \multirow{2}{*}{ Species } & \multirow{2}{*}{ No. } & \multirow{2}{*}{ Sex } & \multirow{2}{*}{ Age } & \multirow{2}{*}{ Material } & \multirow{2}{*}{ Site } & \multirow{2}{*}{$\begin{array}{l}\text { Exan- } \\
\text { thema }\end{array}$} & \multicolumn{2}{|c|}{ Temperature } \\
\hline & & & & & & & $\begin{array}{c}\begin{array}{c}\text { Febrile } \\
\text { stage }\end{array} \\
\end{array}$ & $\begin{array}{c}\text { Maxim- } \\
\text { um }\end{array}$ \\
\hline \multirow{6}{*}{ Sheep } & \multirow{2}{*}{22} & \multirow{2}{*}{$\delta$} & \multirow{2}{*}{$\begin{array}{c}6 \\
\text { months }\end{array}$} & $\begin{array}{l}\mathrm{V} \text { and } \mathrm{N} \\
\text { filtrate }\end{array}$ & \multirow{2}{*}{$\begin{array}{l}\text { Lip, } \\
\text { thigh, } \\
\text { nose }\end{array}$} & Lip & \multirow[b]{2}{*}{$1-16$ days } & \multirow[b]{2}{*}{$40.7^{\circ} \mathrm{C}$} \\
\hline & & & & $\begin{array}{l}\text { Non- } \\
\text { filtrated }\end{array}$ & & $\begin{array}{l}\text { On all } \\
\text { sites in- } \\
\text { oculated }\end{array}$ & & \\
\hline & \multirow{3}{*}{23} & \multirow{3}{*}{$=$} & \multirow{3}{*}{$=$} & $\begin{array}{l}\mathrm{V} \text { and } \mathrm{W} \\
\text { filtrate }\end{array}$ & \multirow{3}{*}{$=$} & Lip & \multirow{3}{*}{ 3-12 days } & \multirow{3}{*}{$40.8^{\circ} \mathrm{C}$} \\
\hline & & & & $\begin{array}{l}\text { Seits EK } \\
\text { filtrate }\end{array}$ & & - & & \\
\hline & & & & $\begin{array}{c}\text { Non- } \\
\text { filtrated }\end{array}$ & & $\begin{array}{l}\text { On all } \\
\text { sites in- } \\
\text { oculated }\end{array}$ & & \\
\hline & $7 *$ & $=$ & $\begin{array}{c}4 \\
\text { years }\end{array}$ & V filtrate & Lip & Lip & - & $39.7^{\circ} \mathrm{C}$ \\
\hline
\end{tabular}

* : Sheep No. 7.... Reinfection (about 2 years after the natural infection) first place, the exanthematous lesion on its incipient stage was taken out, and filtered through Berkefeld $\mathrm{V}$ and $\mathrm{N}$ filters. The filtrates were inoculated on the lip, nose, and thigh of a healthy sheep (No. 22, 6 months). As the result, of retarded appearance exanthema was observed on the lip with lesser severity than that of the sheep inoculated with non-filtrated materials. In the next place, an exanthematous portion of Sheep No. 22, was emulsified and filtered through Berkefeld V, W and Seitz EK filters. Each filtrate was inoculated on the lip, nose and thigh of a sheep (No. 23). The animal developed fever. When Seitz filtrates were inoculated, no appreciable change was observed at the sites inoculated, but when $\mathrm{V}$ and $\mathrm{W}$ filtrates were inoculated, formation of exanthema and scab was observed on the lip only. At the same time, when V filtrate was inoculated on a sheep (No. 7) which had experienced the infection 2 years ago, exanthema was observed ten days 
after inoculation, the immunity being expired. In this experiment, the animals used were only sheep, and owing to the high price of the test animals, it was impracticable to get sufficient number of animals necessary for running quantitative immunological experiments, and consequently, detailed informations as to the grade and duration of immunity were not obtained. While undertaking experiments with the filtrates, exanthema was observed on the lip at the site of inoculation, then on the opposite side of the lip, this fact may indicate that this disease is contagious.

\section{Experimental inoculation on small animals and cultivation of virus in tissues}

Parallel to the afore mentioned experimental infection on sheep and goats, the emulsion of scab and filtered materials prepared in the same manner as mentioned in the preceding experiments, were inoculated on small animals of several kinds and the causative agent was cultivated on chorioallantoic membrane of embryonated eggs and also on chick embryo tissues by Zinsser's method. And blind passages were performed for the most part, namely, inoculations were made in the brain, cornea, lip, thigh, and testicle of 15 rabbits, and in the brain, lip, and hoof of 15 guinea pigs, and in the brain (25), abdominal cavity (20), nasal cavity (20) and skin (10) of 75 mice, and in the skin of 2 hens, but no paticvular change was observed. Materials obtained from the rabbits of the 2nd 4th generations of the causative agent which passed through testicles of rabbits and the ninth generation of the causative agent which passed through embryonated eggs, and the ninth and eleventh generations of the causative agent cultivated by Zinsser's method were inoculated on the lip of a healthy sheep (No. 24), but the results were negative in all of them.

\section{Histological findings}

Histological examinations were made on eight animals experimentally infected ( 2 animals 4 days, 3 animals 6-7 days and 3 animals 10-12 days after inoculation). Materials used for the inoculation were exanthematous portion at the site of inoculation. For fixing, formalin, absolute alcohol, and Dubosoq Brazil Bouin's fluid were used. In addition to haematoxylineosin staining, Mann's staining, Laidlaw's staining, Azan staining, Feulgen reaction, methyl green pyronin staining and van Gieson's staining were employed. As principal lesion, proliferation, swelling, vacuolar degenera- 
tion and necrosis of the germ layer of the cuticle were observed. At the same time exsudation and infiltration between stratum granulosum and stratum lucidum and formation of vesicle and pustule were observed. Pustule was composed of polymorphonucleus leucocytes chiefly and was mixed with pieces of necrobiotic cell and crushed nucleus. When pustule burst out, scab was formed. The lesions often became serious by bacterial contamination. Eosinophile inclusion bodies were found in protoplasm of swollen degenerated cells of the preparations of primary vesicle and pustule obtained from 2 animals (4th day and 7th day after inoculation) experimentally infected with non-filtrated materials. This inclusion body was found solely or as conglomeration, having irregular size with round or irregular periphery and non-stained zone was observed around it. The nucleus of the cell including the inclusion bodies was found pressed and deviated. Chromatins were scattered widely, and some cells were absent of nucleus. The inclusion bodies did not stain by methylgreen pyronin staining, but stained yellow by van Gieson's staining, stained blue by Mann's staining, and stained deep red by Laidlaw's staining. The result of Feulgen nucleric acid reaction was not obtainable owing to the small number of the inclusion bodies. It is impossible to give any definite judgement at present as to whether these bodies can be consider as virus, as Guarnieri does, or are nothing but the degenerated products of cells (Fig 5,6 ).

\section{Discussion and summary}

In the above studies, observations were made on the cases of natural dermatitis of sheep bred at the Veterinary Division, National Institute of Health and those at several other places. Various experiments were undertaken with the materials obtained from those animals. Results are summarized as follows:

This dermatitis is contagious accompanying fever. It develops exanthema in size of a Pin-head on the skin of face, thigh, scrotum etc. at first, then with the lapse of time forms papule, vesicle, and pustule which heal 2-3 weeks afterwards. It propagates by contagion, and appears to have an incubation period of 3-7 days. Exanthema is remarkable especially on the periphery of lips, and lambs are susceptible to this infection. Experimental infection of goats is also practicable. The causative agent of the disease is virus filtrable through Berkefeld V, N and $\mathrm{W}$ filters and not filtrable through Seitz EK filters. Sheep once experienced the infec- 
tion are found acquiring immunity to some extent, but the duration of immunity seems not so long. In the above experiments, attempts to infect small animals were not successful. Cultivation of the causative agent in tissues was not successful. Despite of the evidences signifying the outbreaks of this disease have long been noted in Japan and Korea, detailed experiments have, not been undertaken on account of its mild clinical symptoms and low mortality. Comparisons of the present disease were made with various dermatitis characterized as contagious diseases of sheep which have been reported. The present disease is epidemiologically, clinically and experimentally different from sheep pox, foot and mouth disease, and necrobacillosis on various points. Comparisons of the subject disease with those reported under the names of contagious ecthyma (sore mouth, contagious pustular dermatitis of sheep) and ulcerative dermatitis of sheep (lip and leg ulceration, posthitis, balanoposthitis, ulcerative vulvitis) were also made. These two diseases, described in literatures, bear a striking resemblance to the subject disease in every respect. After the report on contagious ecthyma was made in 1928 by Glover(4) as contagious dermatitis caused by virus filtrable through Berkefeld V filter, many detailed studies were performed by Howarth(5) (1929), Newsom and Cross ${ }^{(9,10)}$ (1931, 1934), Boughton and Hardy(3) (1934), Marsh and Tunnicliff(8) (1937) and other workers. Experimental infections of contagious ecthyma to small animals were made by Boughton and Hardy(3) (1934), Kelser and Schoening(6) (1934) et al., but the results obtained were negative. Beveridge and Burnet(1) (1946) reported that the tissue cultivation of the virus of contagious ecthyma was impracticable. On the other hand, many studies have been published on ulcerative dermatitis of sheep, after the reports made as a virus disease by Puller(12) (1931), Tunnicliff and Matisheck(13) (1941). On the difference of ulcerative dermatitis of sheep and contagious ecthyma, Bosworth and Glover(2) (1931) and Tunnicliff (14) (1949) wrote that though there is a remarkable clinical ressemblance in those two, they are discernible by cross immunization experiment. At present it is impracticable to get virus strains of contagious ecthyma and ulcerative dermatitis of sheep, and consequently exact differentiation of those two from the present disease is impossible. The authors here only insist that epizootologically, clinically, and experimentally there is a striking ressemblance among them. 
Human cases with natural infection of contagious ecthyma are reported by Newsom and Cross(11) (1934) and Lloyd(7) et al. but human infection of the present disease was not observed during the period of investigations made on the epizootics, in the infected areas.

The authors wish to express their heartfelt thanks for the assistances rendered by Drs. Kawashima and Ichikawa of the Government Experimental Station for Animal Hygiene and Prof. Kawakita of the Chiba University School of Medicine.

\section{REFERENCES}

(1) Beveridge, W. I. B., and F. M. Burnet: The cultivation of viruses and rickettsiae in the chick embryo. Spec. Rep. Series Med. Res. Counc., London, No. 256, 1946.

(2) Bosworth, T. J., and R. E. Glover: Some observation on the nature of certain disease of shreep. Proc. Forty-ninth Ann. Cong. Nat. Vet. Med. Ass. Great Britain and Ireland, 1931. [Cit. by Tunnicliff, E. A.: Amer. J. Vet. Res., 10, 240-249 (1949)].

(3) Boughton, I. B., and W. T. Hardy: Contagious ecthyma (sore mouth) of sheep and goats. J. Amer. Vet. Med. Ass., 85, 150-178, 1934.

(4) Glover, R. E.: Contagious pustular dermatitis of sheep. J. Comp. Path. and Therp., 41, 318-340, 1928.

(5) Howarth, J. A.: Infectious pustular dermatitis of sheep and goats. J. Amer. Vet. Med. Ass., 75, 741-760, 1929.

(6) Kelser, R. A., and H. W. Schoening: Virus of contagious ecthyma (contagious pustular dermatitis). Manual of Veterinary Bacteriology, $546-547,1943$.

(7) Lloyd, G. H., A. Hacdonald., and R. E. Glover: Human infection with the virus of contagious pustular dermatitis. Lancet, 260, 720-721, 1951.

(8) Marsh, H., and E. Tunnicliff: Stomatitis in young lambs involving Actinomyces necrophorus and the virus of contagious ecthyma. J. Amer. Vet. Med. Ass., 91, 600-605, 1937.

(9) Newsom, I. E., and F. Cross: Some complication of sore mouth in lambs. Ibid., 78, 539-544, 1931.

(10) Newsom, I. E., and F. Cross: Sore mouth in feeder lambs due to a filtrable virus. Ibid., 84, 233-247, 1934.

(11) Newsom, I. E., and F. Cross: Sore mouth in sheep transmissible to man. Ibid., 84, 799-802, 1934.

(12) Puller, E. M.: Unpublished, 1931. [Cit. by Filmer, J. F.: Austr. Vet. J., 14, 47-52 (1938) ].

(13) Tunnicliff, E. A., and P. H. Matisheck: A filtrable virus demonstrated to be the infective agent in ovine balano-posthitis. Science, 94, 283-284, 1941.

(14) Tunnicliff, E. A.: Ulcerative dermatosis of sheep. Amer. J. Vet. Res., 10, 240-249, 1949. 


\section{Explanation of Plates}

Fig. 1. Face exanthema of naturally infected sheep. (Sheep No. 3).

Fig. 2. Lip lesions produced by inoculation with Berkefeld V filtrate. (Sheep No. 19).

Fig. 3. Lip lesions produced by inoculation with scab emulsion. (Sheep No. 19).

Fig. 4. Lip lesions produced by inoculation with scab emulsion. (Goat No. 3).

Fig. 5. Lip lesion (Goat No. 6). 7 days after inoculation with scab emulsion. Bouin fix., haematoxylin-eosin stain. (about $\times 150)$.

Fig. 6. Magnification of Fig. 5. Arrows show inclusion-bodies. (about $\times 800$ ). 
Fig 1

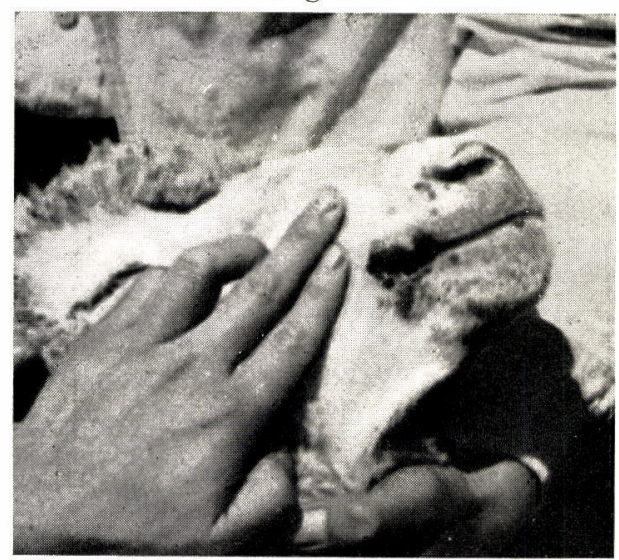

Fig 2

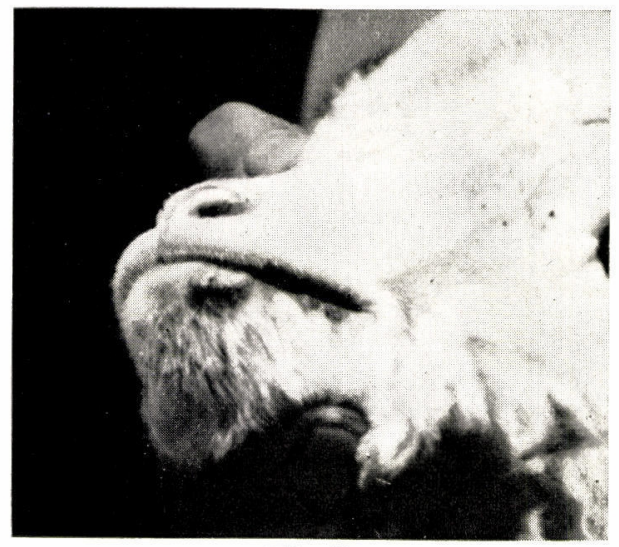

Fig 5

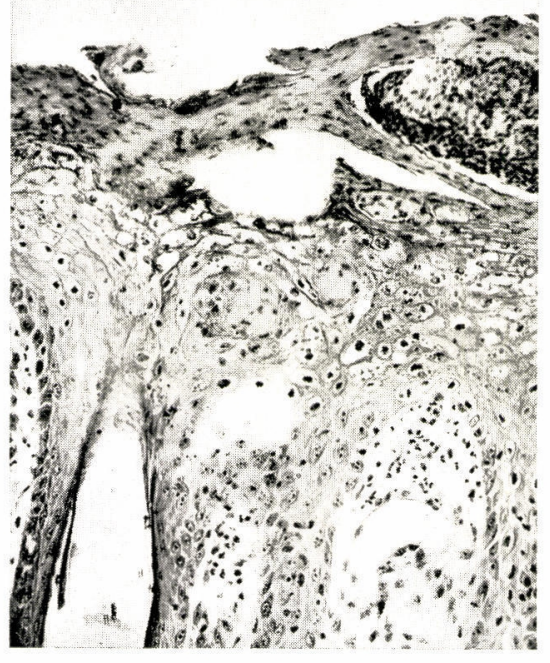

Fig 3

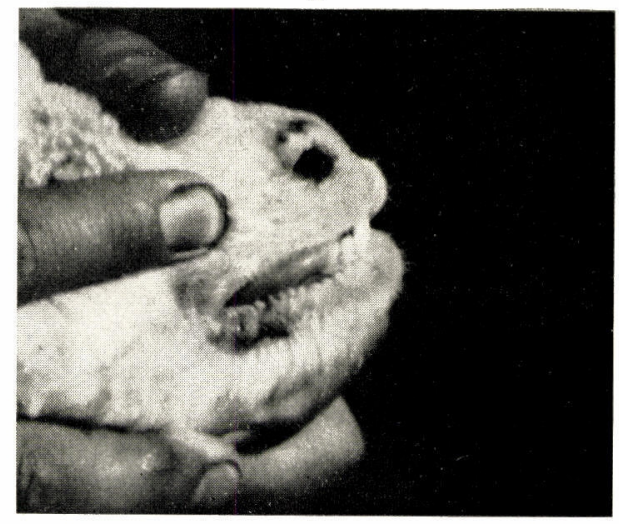

Fig 4

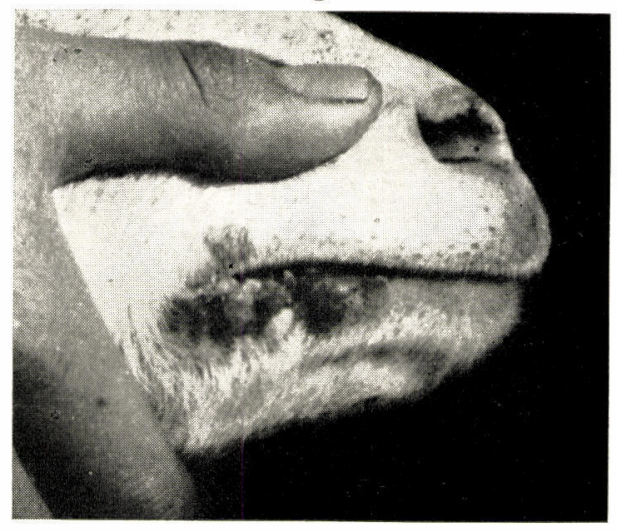

Fig 6

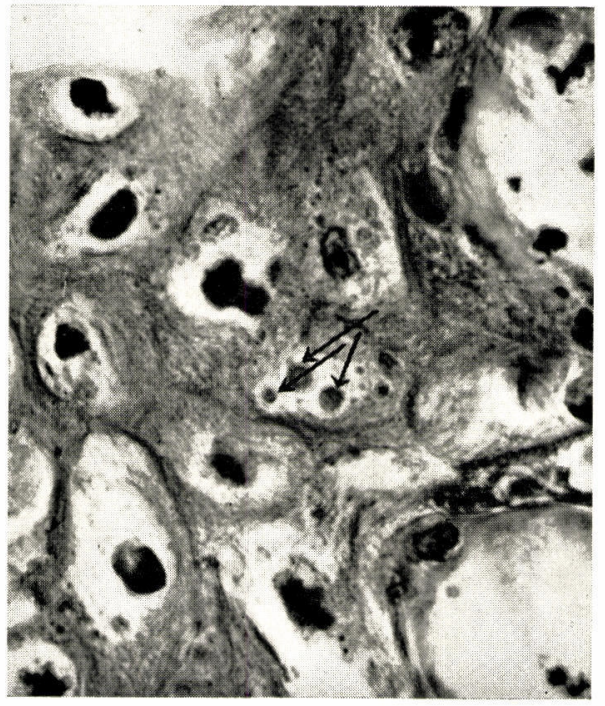

